\title{
THE ZIONIST PRESS ON LITHUANIAN-JEWISH ECONOMIC RIVALRY IN THE 1930s
}

\author{
Eglè Bendikaitè
}

ABSTRACT The Zionists were fully aware that the ideal that they propagated in relation to the creation of a political home for the whole Jewish nation could not be implemented overnight. Therefore, the concern about the socio-economic situation of the Jewish community was one of the main issues of Zionist activity in the Diaspora. The consequences of the world Depression of the 1930s, domineering nationalistic ideology, a big wave of anti-Semitism in Western Europe aroused strong public emotions in Lithuania, which manifested themselves mainly in the struggle for the 'neglected' economic positions in the country.

This article attempts to reveal how the economic rivalry between the Lithuanians and the Jews was seen and presented in the Zionist press, most widespread and widely read by people of various political viewpoints in the 1930s. The information contained in the Zionist press throws light on the formation of the attitude towards the national economic programme conducted by Lithuanian authorities, placing emphasis on the importance of export and import, the qualification examination of artisans, the law on holidays and rest days, etc. Attention is also paid to the propaganda of the Association of Lithuanian Merchants, Manufacturers and Artisans (established in 1930), and the specifics of their rhetoric. The press response to professional competition, narrowing the spheres of the engagement of Jews and the propaganda of hatred towards the Jewish nation are also dealt with.

A monthly of the Jewish Union of small tradesmen wrote in its introductory article of the first issue in 1935:

Politics and economics are two ruling dictators. ... both of them are equally powerful and assert dominance over humanity, its culture and civilisation. Politics and economics are conjoined like Siamese twins. Economics suffer due to bad politics, while the most stable political relations can deteriorate in the aftermath of economic crises ...

${ }^{1}$ R. T. 'Unzere ciln', Unzer Handl, 1 (1935), p. 1. 
In the period between the sixteenth and nineteenth centuries, Jews, having brought industrial and commercial skills to this provincial country, stimulated the development of capitalism, while their presence and monopoly in industry, commerce and handicrafts became undesirable in independent Lithuania. After the recovery of independence Lithuanians began to settle in towns and cities, traditionally inhabited by people belonging to other ethnic groups. That led to the development of a new social structure and new economic relations. Being politically independent, Lithuanians strove for economic independence, i.e. they began recovering their positions in handicrafts and trade, which until that time were occupied by Jews. The degree of this 'self-consciousness', treated by Jews as a measure aimed against them and by Lithuanians as a normal way of self-defence in economic competition for lost positions, had been increasing until the loss of Lithuanian independence in the late thirties.

In the interwar period the socio-economic factor played possibly the most crucial role in the Lithuanian-Jewish relations, and therefore it was analysed in various respects in the works of Lithuanian and Jewish authors. In his study on the course for the state-controlled economy, Gediminas Vaskela dealt with the national LithuanianJewish contradictions in a purely economic context. ${ }^{2}$ Bernaras Ivanovas investigated the socio-economic relations between the Lithuanians and the Jews against a background of the formation of Jewish images in the ideology and propaganda of the Nationalist Party. ${ }^{3}$ Solomonas Atamukas and Dov Levin meticulously presented the economic state indexes disadvantaging the Jews by analysing a deliberate Lithuanisation policy of economy supported by the government and its organisations and its effect on the relations between the two ethnicities in the interwar period. ${ }^{4}$ It is noteworthy that all authors dealing with Lithuanian-Jewish relations between the two world wars agree that modern anti-Semitism, spawned by nationalism and based on the disproportion in the national economy of the country, grew in the sphere of economic and social rivalry supported by nationalist policy. ${ }^{5}$

${ }^{2}$ G. Vaskela, Lietuva 1939-1940: kursas $\dot{i}$ valstybès reguliuojama ekonomika (Vilnius, 2002).

${ }^{3}$ B. Ivanovas, Tautiškumo beieškant Antano Smetonos Lietuvoje (Vilnius, 2005).

${ }^{4}$ S. Atamukas, Lietuvos žydu kelias nuo XIV a. iki XX a. pab. (Vilnius, 1998); D. Levin, Trumpa žydu istorija Lietuvoje (Vilnius, 2000).

${ }^{5}$ E. Mendelsohn, The Jews of East Central Europe between the World Wars (Bloomington, In., 1987); V. Berenis, 'XIX a. nacionalinis judejjimas: lietuviai 
The aim of this article is to take a glance at the participants of the process 'on the other side of the barricades' and to show how the economic rivalry between the Lithuanians and the Jews was viewed and presented in the Zionist press of the 1930s. In Lithuania in this period there were five Jewish dailies; they were published in Yiddish for four to ten years without interruption. Four of them Di Yidishe Shtime and its the evening supplement Haintike Nais, Dos Vort and Unzer Moment - belonged to the Zionist-wing, i.e. they were issued by General Zionist, Socialist Zionist and Revisionist Zionist organisations respectively. ${ }^{6}$ Di Yidishe Shtime, the most long-lived periodical, published for two decades, was perceived as the newspaper of the entire Jewish community in interwar Lithuania and read by people of different political views; it was nevertheless an organ of the General Zionists, at least partially reflecting Zionist thinking. Its editorial board also consisted of activists of the Lithuanian Zionist organisation. The daily had about 500 subscribers and its circulation averaged nearly 6,000 copies in the second half of the 1930s. Haintike Nais, smaller and cheaper than Di Yidishe Shtime, was even slightly more popular and had the largest circulation of all dailies (on the average 6,675 copies), though the number of its subscribers reached only over 200. This Zionist periodical was not surpassed by the weekly Apžvalga, which was published in Lithuanian and soon became popular, with a circulation of 5,100 copies and the number of its subscribers being 4,500 on average. ${ }^{7}$ Consequently, these periodicals were the most influential in forming the general public opinion of the Lithuanian Jewish community about events at home and abroad.

No matter in what state the Jews lived, what their education was, or which social layer they belonged to, they always sought to

ir žydai‘, Metai, 6 (1997); A. Eidintas, Žydai, lietuviai ir holokaustas (Vilnius, 2002); S. Sužiedèlis, 'The Historical Sources for Antisemitism in Lithuania and Jewish-Lithuanian Relations during the 1930's'; V. Sirutavičius, 'Notes on the Origin and Development of Modern Lithuanian Antisemitism in the Second Half of the Nineteenth Century and the Beginning of the Twentieth Century', The Vanished World of Lithuanian Jews (Amsterdam - New York, 2004); L. Truska, V. Vareikis, Holokausto prielaidos: antisemitizmas Lietuvoje (Vilnius, 2004); L. Truska, Lietuviai ir žydai: nuo XIX a. pab. iki $1941 \mathrm{~m}$. birželio (Vilnius, 2005), et al.

${ }^{6}$ N. Feigelman, D. E. Fishman. 'Reshime yidishe periodishe oisgabes in der umophengiker Lite, 1919-1940', YIVO Bleter, II (New York, 1994), pp. 349-375.

${ }^{7}$ Spaudos lentelès 1935-1939, LCVA, f. 378, ap. 5, b. 4342, fos. 32, 39, 49$52,80,99-100,105,108-109,112$. 
obtain equal social and political rights. The material well-being of Jewish communities and the independent development of their cultural life depended on their ability to represent their community in its integration into the internal life of the state. Declaring the creation of the political home for the entire Jewish nation in Palestine, the Zionists never maintained that the 'bright vision' could be implemented in a short time. Zionist propaganda treated life in the galuth (Hebrew for 'exile') as an intermediary stage, in which the forces of the Jewish nation should not be wasted. However, as early as 1906 the Zionist conference of all Russia in Helsinki adopted a new programme, entitled 'Activity Here and Now', stressing the necessity of representing and defending the interests of the Jewish masses in the Diaspora as well. ${ }^{8}$ The concern for Jewish life in the Diaspora and the improvement of the economic and social situation of the nation were the principal trends of the activity indicated in the programmes of individual factions of the interwar Zionist organisation of Lithuania. ${ }^{9}$ Serious attempts were also made to participate in the Seimas and self-government institutions and to influence the adoption of laws regulating the country's economic life through their representatives.

In any national state the endeavours of the government to support the national majority in all spheres of life and, in particular, in those where its role was insignificant, should be understandable. The policy of the Lithuanian government to create conditions favourable for the growth of Lithuanian capital was caused by agelong ethnic disproportion in industry, commerce, handicrafts, and the professions. In its attempts to establish a normal civic pyramid of Lithuanian society the Lithuanian government followed a course of reconstruction of the economic life of the country. In the late 1920s Lithuanian ruling circles began to concentrate many business spheres in their hands. Lithuanian Jews before long became aware of the changes in those fields of economy, to which the government turned its attention, in particular in monopolising the imports and exports.

In the early $1930 \mathrm{~s}$, when the government was searching for ways to counter the consequences of the world Depression, the

8 'Helsingfors program', Encyclopedia of Zionism and Israel, ed. R. Patai, 1 (New York, 1971), p. 318.

${ }^{9}$ M. Kahan, 'Der algemainer tsionizm in der zelbshtendiker Lite', Lite, 2 (Tel Aviv, 1965), p. 76; Sh. Fridman, 'Di tsionistishe sotsialistishe bavegung in Lite', Lite, 2, p. 69. 
press started looking for recipes for solving the crisis and for new markets for Lithuanian products. Exploiting the potential and experience of the lawyers and economists of the Jewish community the Zionist press offered its variants presenting them as their concern for the interests of the whole country. An 'efficient' measure, proposed by the official government paper, Lietuvos žinios, to limit imports radically and to boycott the production of those countries that did not buy Lithuanian goods, was greeted sceptically by $D i$ Yidishe Shtime. The Jewish newspaper maintained that a rash and thoughtless decision to resort to boycott could complicate Lithuanian matters on the world markets, and instead suggested that internal resources should be used, namely that, import tax on luxury goods, such as cars, silks, furs, etc. be increased. ${ }^{10}$ By reprinting an article from $M \bar{u} s u$ rytojus, which stated that 'due to the attention of the government to the united export organisations, private exports were in deep trouble', the editors showed that economic reasoning was not the prerogative of their newspaper. It was regretted that the selected organisations failed to measure up to their task. They did not solve the problem of selling goods abroad, and limiting import due to export failure was dangerous, while export subsidy could unbalance the budget. ${ }^{11}$ The editors were a little surprised by the conclusion of Mūsu rytojus that the large cooperatives (Maistas, Pienocentras, Lietūkis, and others) were turning into export monopolies, and individual capital and initiative were being eliminated systematically. However, in the future a niche should be left for people, experienced in export, and that 'would serve the interests of Lithuania and its people'. ${ }^{12}$

The government's national economic programme was analysed first against the background of common economic processes and growing harmful tendencies in the national economy rather than through the prism of the search for anti-Jewish activities. A new project of cooperation reform was discussed at the end of 1934 and was overtly referred to as a law for 'the establishment of new state institutions', impeding a spontaneous development of cooperation. When a planned activity was presented as a freedom for the initiative of all citizens the government retaining the controller's role, one thing remained unclear, that is 'the absence of the question of

10 'M'zol bagrenitsen import', Di Yidishe Shtime, 266, 20 Nov. 1932.

11 'Umtsufridnkait mit eksport-organizatsies', ibid.

12 Ibid. 
responsibility' ${ }^{13}$ An increase in the purchase prices of milk products made by Pienocentras, which allegedly equalled the prices of oranges, was treated as bringing to ruin both Jewish and Lithuanian retailers. $^{14}$

At the same time the Jewish press started reporting new stories about the state capital outrivaling Jewish syndicates in logistics, timber and flax export and branches of import belonging to the state monopoly. Thus the Jews were pushed to the sidelines of the market and deprived of their traditional means of subsistence. ${ }^{15}$ The law, regulating the reorganisation of flax trade and giving the right of its export to one enterprise or their association, was adopted on 1 October 1934. Visits of influential Lithuanian economists to the government and the memoranda of Lietükis in relation to such a 'topical' issue as flax trade that could be saved only through centralisation produced the desired results, Di Yidishe Shtime noted ironically. '.. it is quite clear what the aim of the project of this law is and what its consequences can be', and it was only a question of time when the envisaged theoretical possibility to be further engaged in this business will disappear without trace. ${ }^{16}$ 'Flax export and the role of middle-man were old Jewish occupations in Žemaitija and northern Lithuania', Dos Vort stated. 'Now it seems to us that this branch of foreign trade has fallen in the storm of centralisation policy'. ${ }^{17}$ This was not an unprecedented case. Formerly such a tendency had been observed in egg exports, when Pienocentras had been cast in the role of a similar rescuer. ${ }^{18}$ The state interfered in business not only by controlling the quality of the product proper but

13 'Tsi darf sikh di regirung mishn in kooperatsie', Dos Vort, 90, 3 Dec. 1934.

14 'Pienocentras konkurirt mit kremer', Dos Vort, 14, 17 Jan. 1938.

15 The following are only some of the reports, which appeared in the course of several months: 'Konkrete shrit tsu tsentralizirn flaks handel', Di Yidishe Shtime, 249, 3 June 1934; Y. Zh., 'Erev tsentralizatsie fun flaks-eksport', ibid, 258, 7 June 1934; 'Tsentralizatsie fun vald-eksport', Dos Vort, 49, 15 Oct. 1934; 'Private unternemungen (Maistas, Tsuker Fabrik, Lietukis) mit investirt melukhishn kapital' ibid, 56, 24 Oct. 1934; 'Eingefirt kontrol oifn flaks eksport', idem, 63, 1 Nov. 1934; Sh. B-r, '10-fakhike praizn yeride fun litvishn eksport legabe praizn yeride fun import', idem, 64, 2 Nov. 1934; 'Tsi darf sikh di regirung mishn in kooperatsie', idem, 90, 3 Dec. 1934.

16 'Konkrete shrit tsu tsentralizitn flaks handel', Di Yidishe Shtime, 249, 3 June 1934.

17 'Eingefirt kontrol oifn flaks eksport', Dos Vort, 63, 1 Nov. 1934.

${ }^{18}$ Y. Zh., 'Erev tsentralizatsie fun flaks-eksport', Di Yidishe Shtime, 258, 7 June 1934. 
also by setting corresponding standards and fines for their violation. Special commissions, consisting of representatives of various ministries, the Chambers of Agriculture and Commerce and other institutions (among whom there were no Jews), examined brokers, many of whom, according to Zionist dailies, left such branches of trade and industry voluntarily due to various licence and quota restrictions. ${ }^{19}$

Writing about economic matters important for the Jewish community, the contributors to the Zionist Jewish dailies tried to interview high state officials. ${ }^{20}$ However their promises 'to attend to that matter, to see to it' could hardly show an ordinary Jewish trader or craftsman what law amendments were in store for him and what trends of economic policy could change his activity.

The interwar Nationalist governments of Lithuania adopted a score of laws and their revisions thereof, such as amendments to the Law on Export and Import, the Law on Advocacy, the Laws on Price Regulation, on Ranks, on the Chamber of Physicians, which in one way or another affected a large part of the Jewish community and could not be ignored in the Zionist press. One of the laws, which caused a clamour in the Jewish community, was entitled the Law on the Commission of Business Examination; it was issued at the beginning of 1934. The preparation of competent artisans had to include an examination according to the curriculum of at least four grades of public education. This examination had to be taken by those who wanted to obtain the licence of a qualified artisan. The success of passing the examination depended largely on the command of the official state language. The examination commission was set up and its activity was controlled by the Ministry of Education. $^{21}$ The application of the new law in practice could mean the

19 'Konkrete shrit tsu tsentralizirn flaks handel', ibid., 249, 3 June 1934; Y. Zh., 'Erev tsentralizatsie fun flaks-eksport', ibid, 258, 7 June 1934; 'Tsentralizatsie fun vald-eksport', Dos Vort, 49, 15 Oct. 1934; 'Eingefirt kontrol oifn flaks eksport', ibid., 63, 1 Nov. 1934.

${ }^{20}$ Y. Zh., 'Vi halt mit unzer handl un indutrie? Geshprekh mitn forzitser fun handls-komer h. Dobkevičius', Di Yidishe Shtime, 11, 8 Jan. 1934; 'Di antviklung fun unzer virtshaft in likht fun biudzhet. A geshprekh mitn vitse finans minister Indrashiunas vegn aktuele ekonomishe frages', Dos Vort, 150, 5 July 1936; 'Di antviklung fun unzer virtshaft in likht fun biudzhet. A geshprekh mitn vitse finans minister h. Y. Indrishunas', Unzer Moment, 151, 6 July 1936; L. Vilski, ‘Aktuele miskher un hantverker inyonim. A geshprekh mitn forzitser fun handlkomer h. Kurkauskas', Dos Vort, 3, 4 Jan. 1938, etc.

21 'Verslo egzaminų komisijos įstatymas', Vyriausybès žinios, 440, 2 March 1934. 
elimination of the older Jewish generation from the labour market since only very few people could succeed in passing the written and oral examinations in the Lithuanian language.

Following the official publication of the law in Lietuvos žinios, Di Yidishe Shtime reported briefly about the adoption of the law at the session of the cabinet of ministers. It indicated the main points of the law and added that the Ministry of Education had to issue the regulations about its practical implementation. ${ }^{22}$ However, the fact that the essence of the law and, what was more important, its consequences for Jewish artisans were known not only from the press was attested by an article of a representative of the Jewish artisans union Leiba Gurvich a day earlier. He expressed doubts about the necessity of the examination only as a guarantee to have competent and qualified artisans. 'We are aware that it often happens that what is read is not what is written'. ${ }^{23}$ Gurvich indicated that the basic point was that there were plans to establish a union of artisans, which eventually was to become the main representative and defender of the interests of all artisans. It was also clear that only 'hundred-per-cent' artisans, namely those who passed the obligatory examination, could be elected to its executive bodies. ${ }^{24}$

The organisation representing the interests of artisans took practical measures. On 4 April 1934 the representatives of Jewish communities sent telegrams from different parts of Lithuania to the minister of education in Kaunas. All the telegrams were almost identical. They contained a request to suspend the activity of the business examination commission or to amend the law itself. ${ }^{25}$ It was hoped that this law would not hold true for those already in business; otherwise measures would have been taken for as many Jews as possible to pass the examination. In his article, Gurvich described a 'radical' adequate measure, practiced by the Associations of Jewish Artisans and Jewish People's Banks - evening courses of the Lithuanian language for adult artisans in Kaunas and in the provinces. In Kaunas there were two groups learning to read, write and speak Lithuanian.

22 'Forefntlikht gezets vegn ekzamens-komisie far farsheidener profesies', Di Yidishe Shtime, 106, 4 March 1934.

${ }^{23}$ L. Gurvich, 'Vi darf men lernen litvish mit dervaksene hantverker', Di Yidishe Shtime, 105, 4 March 1934.

${ }^{24}$ Ibid.

${ }^{25}$ Amatininkų kvalifikacijos reikalu 1934, LCVA, f. 605, ap. 3, b. 9, fos. 35-39. 
Younger artisans predominate among the students, but grey-haired middle-aged people can also be seen. ... Nobody knows how long this will last, but it is an extraordinary phenomenon when after a long day's work and their household chores the artisans gather three times a week with books and copybooks and sit and study at the same desks at which their children sat several hours ago. It is not easy to teach adults who cannot get daily worries out of their heads, and it is even more difficult for the artisans who do their best to understand what the teacher is saying, because all kinds of qualms race involuntarily through their minds. Nevertheless, a great wish to learn the Lithuanian language is evident. ${ }^{26}$

Although Gurvich saw the progress made, he proposed to change the methods of teaching, because '... artisans study and devote their time, health and money not to learn the subjects of the school curriculum'; the courses should be useful in taking the artisan qualification examination. In Gurvich's opinion attention should be focused on the phrases and terms related to the professional practice of the students and their handicraft in the broad sense, and to the communication between the artisan and his customer or his employees not only in Yiddish but also in Lithuanian. ${ }^{27}$ The editors of $D i$ Yidishe Shtime, conceiving this problem as peculiar not only to this one social stratum but also to the entire Jewish community, added their own postscript to Gurvich's article stating that the problem must be solved without delay: "neither time, nor the crux of the matter, nor the use derived justify old methods. In our opinion, a special teaching commission must be appointed to prepare a programme better adapted to the aims of the artisan courses' ${ }^{28}$

Exemption from the qualification examination even of the most experienced artisans was the prerogative of the minister of education. Following the publication of the law the representatives of both Jewish communities and other interested groups addressed the minister. The Zionist press was interested in the position of the workers who also had to experience the weight of the new law. However, it turned out that the potential allies viewed the situation differently and tried to survive with as little losses as possible. The letter to the minister also noted the workers' request of certain concessions as regards the qualification examination, the composition

${ }^{26}$ L. Gurvich, 'Vi darf men lernen litvish mit dervaksene hantverker', Di Yidishe Shtime, 105, 4 March 1934.

${ }^{27}$ Ibid.

${ }^{28}$ Ibid. 
of the commission and the pay for the licences. The information contained a rhetorical question as to why no mention was made of the essence of the examination and relevant exceptions. 'Were the workers not concerned about the position of elderly craftsmen who had good work experience but could not pass the examination any more?'. ${ }^{29}$

Discussions about this law flared up in public time after time. In the middle of 1936 a routine conference of the Amalgamated Association of Jewish Artisans took place to discuss the work done in the first half-year. The press enumerated all visits of the central board of the Union to the ministers of education, home affairs and finance, and the memoranda on the drafts of the laws or their amendments then under consideration related to taxes, professional practice and employment. Without going into more detail, it was noted that the Union took continuing care of the organisation of the evening courses of Lithuanian for the artisans. However, the aim to develop language training in the provinces was not implemented because the minister of education did not respond to the request of the central board to set up such courses in the shtetls. ${ }^{30}$ The Association of Jewish Artisans closely cooperated with the Association of Jewish People's Banks, therefore it is little wonder that the latter Association adopted a separate protest resolution condemning the artisan qualification examination in its sixteenth congress in $1936 .{ }^{31}$

At last the ruling circles decided to release from the examination those artisans who had started work in the fields of industry, commerce and handicrafts before the adoption of the law. The exception to the law came as a welcome relief to the Jewish community. However, at the beginning of 1938 Di Yidishe Shtime informed its readers about two new drafts of the Law on Artisans. The daily reported that the main principles of the law on artisans and of the project of artisan register, 'allegedly to be published and implemented already this year', should be made public soon. According to the first document, artisans were to be divided into three categories: (a) masters having their own shops, workers and

29 'Vos vintsht arbeter-farshteiershaft vegn hantverker-ekzamens', Di Yidishe Shtime, 257, 7 June 1934.

${ }^{30} \mathrm{G}-\mathrm{Z}$. 'Baratung fun tsentral rat, tsentral farvaltung un aktive hantverker tuer fun allitvishn fareiniktn hantverker farband', Unzer Moment, 152, 7 July 1936.

${ }^{31}$ Ibid. 
apprentices, (b) junior masters working independently in their own shops but having no right to employ and apprentice, and (c) qualified craftspersons. To the knowledge of the editors discussions in the official circles centred mainly on the status and rights of the old members, while the interested groups, that is, Lithuanian businessmen, sought the wording of the law preventing the rise of the majority of Jewish artisans above the level of the category of craftspersons due to their qualifications and work experience. ${ }^{32}$ The report did not present any other comments, it merely stressed that the full text of the law would be published in the near future.

The law on holidays and rest days was adopted in the early ' $20 \mathrm{~s}$, but its realisation proved to be much more difficult. After several amendments (Vyriausybès žinios, 328 (1930), 445 (1934)) this law did not lose topicality and was discussed even at the end of the fourth decade. It had turned into an old unending conflict between Lithuanian and Jewish businessmen and violations of the law on the part of the Jews. Sunday was declared the official day of rest; however the Jews, keeping the Sabbath, shifted the rest day to Saturday and traded on Sunday as on an ordinary week day. The stratum of Lithuanian tradesmen and businessmen, evolving in the thirties and willing to have an exceptional position in all spheres, were not only inclined to reconcile to the existing practice, but also to make the Jews observe the law requiring that Lithuanian salesmen did not trade on Sundays and Lithuanian buyers could buy necessary goods on Saturdays as well. Total prohibition against sales on Sundays was treated by the Jews as unequal rivalry, and consequently they looked for ways of making the law more favourable to Jewish businessmen. The main source of official news - Di Yidishe Shtimeinformed its readers that attempts were made to solve this issue at ministerial level. To this end a special delegation of Lithuanian rabbis paid a visit to the new minister for internal affairs Petras Aravičius and was given a warm reception. The minister promised to take an interest in their problem and was prepared to support the rabbis' request; he hoped that the result would be positive if his colleagues other ministers had similar opinions. But before that he had to give the issue a careful consideration. ${ }^{33}$ The spiritual leaders of the Jewish

32 'Hantverker gezets shoin oifn seider hayom', Dos Vort, 2, 3 Jan. 1938.

33 'Agudat-Harabonim delegatsie intervenirt vegn zuntik-ru-gezets', Di Yidishe Shtime, 14, 16 Jan. 1930. 
community emphasised the importance of the Sabbath in their religion, and said that its non-observance would ruin the traditional rhythm of Jewish everyday life.

The latter action by representatives of the Jewish community did not remain unchallenged in the Lithuanian press. The displeasure at the Jewish request to ease 'the forced celebration of Sunday' triggered off the reaction of the newspaper Rytas, and in its turn $D i$ Yidishe Shtime called the newspaper overly Catholic. The remark that 'there is not a single civilised country in which trade on Sundays and holidays is permitted, and the Jews of those countries do not solicit such things from their governments because they take into account the needs of the majority' drew the comment: 'there are many civilised countries which have no laws restricting trade on Sundays'. The newspaper continued:

by requesting exceptions in the aforementioned law, the Jews do not think they hurt the religious feelings of the Christian population; they hold in respect the faith and religious beliefs of their co-citizens. At the same time they note that the Catholic belief does not prohibit trade on Sundays, and until now the Catholic spiritual leaders have never once objected to age-old free trade. ${ }^{34}$

The editors were also astonished by the fact that it was just the Chamber of Agriculture that supported the request concerning the exemption from the law on rest days. That, in their view, showed once again that life itself was against the rest on Sundays obligatory for all, since 'we [this pronoun was often used by the daily to show that it expressed the opinion of the whole Jewish community E. B.] are aware that the law was adopted not due to devotion but to some other motives unrelated to the fear of God'. ${ }^{35}$

Di Yidishe Shtime felt that it was its duty to permanently inform the readers on topical matters of everyday life and to reply to questions addressed to the editorial board. The editor received a letter from Šakių Naumiestis (now Kudirkos Naumiestis) to the effect that newspaper reports produced the impression that exemption from the so-called Sunday rest law would be put into practice soon. As the amendment of this law was of vital importance and the situation was getting worse from day to day, the reader asked the newspaper to inform him and all Lithuanian Jews about the situation

34 'Rytas kegn mildern zuntik-ru-gezets’, ibid., 16, 17 Jan. 1930.

${ }^{35}$ Ibid. 
with regard to the expected amendment at that time. ${ }^{36}$ Ruvin Rubinshtein acknowledged that try as the editors might they could not give a definite answer when 'the promised salvation' would come because they themselves were in a state of complete uncertainty. Their answer was:

Even if we enquired in 'particular institutions', we would not be any the wiser, because 'reliable sources' have assured us time and again that the amendments would be prepared straightaway and would pass through the bureaucratic channels and would be publicised in the form of a law, but ... here begins the story of the familiar 'but...' 37

Unable to give anything new on this matter the editors could only wonder together with the entire Jewish community what made 'particular institutions' proclaim many times in public that the new amendments would soon be adopted and what prevented their appearance. Appealing to prestige and the impropriety for the government 'to change its moods' so easily, the newspaper proposed that somebody in ruling circles should give an answer to the question of an ordinary Jew of Naumiestis. ${ }^{38}$

The menace of the law on holidays was conceived by the activists and authorities of the Jewish community not only in the context of economic indexes. Considerable worries were also caused by possible consequences to the religious consciousness of an ordinary Jewish trader under compulsion to observe the holiday law. ${ }^{39}$ Unzer Moment described in detail an important conference of the representatives of different Jewish layers concerning the Sabbath; it took place in the hall of a Jewish elementary school in Kaunas on 6 December 1936. Rabbi J. Faivlzon delivered a report on the significance and place of the Sabbath in Jewish life in which he emphasised that " ... every devout Jew in the city, strictly adhering to traditions, should be a staunch defender of the Sabbath'. ${ }^{40}$ The debates resulted in the adoption of several resolutions

36 'Fun tog tsu tog. Vos is geshen?', ibid., 8, 9 Jan. 1930.

${ }^{37}$ Ibid.

${ }^{38}$ Ibid.

${ }^{39} \mathrm{Cf}$. the correspondence between the organisations of Jewish traders and the authorities of the city of Kaunas, showing that Jewish shops, factories and workshops were open the whole working day on Saturdays. See also B. Ivanovas, Tautiškumo beieškant Antano Smetonos Lietuvoje (Vilnius, 2005), p. 140.

40 'Groise baratung vegn shabes', Unzer Moment, 274, 8 Dec. 1936. 
and a strong condemnation of the profaners of the Sabbath, who 'by their defiant actions debase and undermine the foundation of the life of the Jewish nation - the holy Sabbath'. The principal resolution stated that

the profaners of the Sabbath and those who do not keep its precepts in their life cannot be elected to any posts in the Jewish community, asked to read the Torah, admitted to the bema (the platform where the Torah is read), allowed to recite Kaddish (at the burial service), be taken into account for the minyan (the minimum number of adult male Jews needed for a religious service) and cannot be buried as Jews. ${ }^{41}$

The latter resolution sounded as the exclusion not only from the believers but also from the Jewish community.

That an ethnic community, no matter how influential it might be, could not require exceptional rights for itself was demonstrated by an attempt of the mayor of Kaunas to prevent any violation of the law on holidays and rest days at least in Kaunas, the provisional capital. His decree on trade on holidays was published in Vyriausybees žinios and had to come into effect on 15 January 1938, however it was suspended by 'higher authorities' at the last minute. The Zionist press had its own sources of information in the municipality and started publishing Jewish response to the decree even before the date of its publication. ${ }^{42}$

The suspension of the decree did not mean its revocation; therefore Dos Vort decided to learn the whole truth at first hand, that is, by talking directly with the senior representatives of the authorities. The newspaper applied to the minister for internal affairs, Julius Čaplikas, and the mayor of Kaunas, Antanas Merkys. ${ }^{43}$ It turned out that Mr Čaplikas was not the best person to apply to. He said he had learnt about it from the press, he did not have a copy of the mayor's decree and could not comment it, and in any case the right of veto was not his prerogative but that of the city council. In his turn, the mayor assured the newspaper that the decree would come into effect; regrettably, he did not know when that would happen

${ }^{41}$ Ibid.

42 'Bafel vegn zuntik ru in Kaunas arain in kraft', Dos Vort, 7, 9 Jan. 1938; 'Men greit naiem ru shteier gezets', ibid., 8, 10 Jan. 1938; 'Farordenung vegn zuntik ru in Kaunas dervail opgeleigt', ibid., 10, 12 Jan. 1938.

43 'Farordenung vegn zuntik ru in Kaunas dervail opgeleigt', Dos Vort, 10, 12 Jan. 1938 . 
and could not say anything about the attitude of other 'responsible institutions'. 44 The editors could merely state that the issue of the working hours of the shops in Kaunas was in the air and its solution was difficult to predict. There remained only one way - to rely entirely on legal loopholes, that is 'to gather the necessary materials and without delay inform the minister for home affairs about the contradictions between the Sunday rest law and the law on local self-government' ${ }^{45}$

Representatives of the Association of Retailers, Messrs Padison and Altfeld also took up the suggestion of the press. Together with the editor Rubinshtein of Di Yidishe Shtime they again visited the minister for home affairs with the same problem. Subsequently Dos Vort wrote that the representatives of Lithuanian traders and businessmen insisted on the publication and accurate implementation of the law under consideration. A case of legal casuistry was mentioned once more by asserting that not the decree would be adjusted to the law, but the law would follow the decree of the Kaunas mayor; and it was stressed that the law on the rest on Sunday would be enforced in Kaunas and county towns, but not in the shtetls. ${ }^{46}$ At least for the time being.

Doubtlessly, both Lithuanian and Jewish journalists closely followed the information published by the other side and did not miss a chance of stinging each other and commenting mutual 'wrong and nasty' statements. The Zionist press was not an exception. When the Lithuanian press declared that it had some 'sensation and hearsay' about the Jews which they themselves did not know, Di Yidishe Shtime felt under an obligation to explain what the Jews were and what their 'real' aims in Lithuania were. ${ }^{47}$ Surprise was expressed at the methods of such important newspapers as Lietuvos aidas and Diena.

With us, in our little world of the press, it is possibly quite fashionable to gather information in cafés, streets or buses or overhearing a telephone talk and sending it to the press ... for instance, one early beautiful

${ }^{44}$ Ibid.

${ }^{45}$ Ibid.

46 'Yidishe delegatsie baim inern minister vegn zuntik ru', ibid., 16, 19 Jan. 1938.

\footnotetext{
47 'Fun tog tsu tog. „Shuts yidn“', Di Yidishe Shtime, 146, 30 June 1936.
} 
morning you can learn about yourself such things which you cannot see in your dreams. It would do no harm for a reporter of such newspapers to pick up the telephone and simply ask a Jewish member of the council whether it is true what is said about ... ${ }^{48}$.

And the answer of Di Yidishe Shtime was categorical: 'It is not true. We are the Jews who do not seek patronage. We do not have any sovereign, any particular superior, whose noble duty would be to defend "his own Jews", 49 There were cases when in response to yesterday's statements relating to the Jews a particular article of a Lithuanian newspaper was re-printed or referred to nearly in full. ${ }^{50}$ On the other hand, cases of strong polemics were rare, this 'right' was reserved for the Lithuanian Apžvalga, the purpose of which was to bring the two communities closer together and to acquaint the readers with the peculiarities and everyday problems of Jewish life in Lithuania.

The attitude to Lithuanian businessmen and their press was quite different. Since its official establishment the Zionist press had been closely watching them 'as if through a magnifying glass'. The Association of Lithuanian Traders, Industrialists and Artisans (also known as the Lithuanian Businessmen's Association), set up in 1930, had to encourage the Lithuanians to engage in business and handicrafts, and to further the aims of economic independence. Their organ Verslas, established two years later, became the principal driving force of economic anti-Semitism. The restriction of 'alien' economic leadership in particular sectors of national economy was directed against concrete subjects, that is, the Jews, although in the early ' 30 s this trend was not expressed overtly yet. ${ }^{51}$ The propaganda of the Lithuanianisation of the national economy over-

${ }^{48}$ Here Jewish members of the Kaunas city council are meant. They represented the interests of the Jewish community and allegedly required privileges of an additional representation in the Seimas.

49 'Fun tog tsu tog. ,Shuts yidn“', Di Yidishe Shtime, 146, 30 June 1936.

50 'Vider antisemitishe hetse, vider bilbulim un narishkait', Haintike nais, 1, 1 Oct. 1934; “"Musu ritojus" iz nit antisemitish', Di Yidishe Shtime, 11, 13 Jan. 1930; "Vi azoi „Verslas“ hetst: arum der maise sindikatn', ibid., 242, 21 Oct. 1932; 'Umtsufridnkait mit eksport-organizatsies', ibid., 266, 20 Nov. 1932; 'Geferlikher veg', ibid., 97, 29 Apr. 1933, etc.

51 'Der verslininkes kongres in Shavl', Unzer Moment, 91, 26 Nov. 1934; 'Oifn verslininkes-tsuzamenfor redt men vegn bakemfn shtarker di yidn', ibid., 273, 7 Dec. 1936. 
stepped the limits of professional rivalry and turned into hatred for a particular nation, although the nationalistically-minded businessmen were not inclined to acknowledge that. According to them, both the Jewish problem and the supposed anti-Semitism were caused by no other factors but by the growth of national consciousness of society and its greater interest in business. ${ }^{52}$ The role of Lithuanians in the non-agrarian sectors of economy increased at the expense of other national groups, mostly Jews; and the businessmen were urged to oust them from their positions. The Jewish press treated that process as a desire to destroy without having built.

It is small wonder that people want to fight for their economic independence and to penetrate into such economic spheres in which their representation has been insignificant so far, but the present situation is extraordinary in that that the founders of the Association [the Lithuanian Businessmen's Association is meant - E. B.] until now have not yet been so disposed towards a harmful reconstruction of Lithuanian economy and have not been guided by such negative slogans against the established situation in trade and industry. ${ }^{53}$

These conclusions were made following the acquaintance with the explanatory letters of the newly established Lithuanian Businessmen's Association, which even did not intend to hide its hostile attitude towards industrialists, traders and artisans of other nationalities. Di Yidishe Shtime regretted that 'alas, our prophecies have come fully true now, since previously there were doubts as to the ways and aims of the Association; however the present congress has cast light on its open and hidden intentions'.54

Without trying to defend its own prejudiced articles, the editorial board of Verslas launched an offensive directed against the Jews and their press. For fear of the competition of Lithuanian businessmen the Jews allegedly slander the Lithuanians, themselves fabricate antiSemitic slogans and incriminate Lithuanian businessmen. 'Spreading the slogan Juden raus

52 'Lietuviškos prekybos organizavimas', Verslas, 7, 7 Apr. 1932; J. Butautis, 'Procesas vyksta', ibid., 32, 6 Aug. 1936.

53 'Geferlikher veg', Di Yidishe Shtime, 97, 29 Apr. 1933.

${ }^{54}$ Ibid.

55 ‘Žydiška logika ir košerna etika', Verslas, 15, 2 June 1932. 
the Jews irritate the Lithuanians. They play the martyrs of themselves. The awakening of Lithuanian businessmen and selforganisation of Lithuanian townsmen seem dreadful to them'. ${ }^{55}$

In their economic activity, relying on private capital and initiative, Lithuanian and Jewish businessmen had to find a basis for cooperation. Allusions to the possibility of common enterprises, albeit rarely, were noticed in the Jewish press, because 'common-sense people' could be found among the businessmen as well, and the economic interests of Lithuanian and Jewish artisans were not at variance. ${ }^{56}$ However that policy totally disagreed with the ideology of the Association of Businessmen, and established contacts were nipped in the bud under the pressure of the authorities. ${ }^{57}$

Businessmen leaders used the categories of economic life in order to substantiate the idea of the cultural difference and intransigence between Lithuanians and Jews. There was a permanent escalation of the image of the Jewish businessman as a materialist, swindler, exploiter, alien, getting rich at the expense of the peasant's labour. However a typical Jewish trader of Lithuania was seen quite differently by the author of Unzer Moment Ish. Sholem. He described his visit to Panevezzys, but the experience of his journey through Lithuanian towns showed that Panevėžys was not an exceptional case and the same characteristics would perfectly suit to describe Jewish traders of Kedainiai, Šiauliai or even of Jatkever Str. in Kaunas (most probably the present Daukšos Str. is meant, where many Jewish meat shops were concentrated). ${ }^{58}$ Further Sholem wrote that he went to one of the biggest shops in the high street to meet its owner, whom he did not find - he had gone to a prayer house in the afternoon. Then the writer dropped into the prayer house and noticed the Jews sitting at a long table and leaning over the Gemara (a commentary of the Talmud, the Mishnah).

56 'Verslininkishe prese konferents tsu propagirn "bloie markes", Dos Vort, 66, 5 Nov. 1934; G-Z. 'Baratung fun tsentral rat, tsentral farvaltung un aktive hantverker tuer allitvishn fareiniktn hantverker farband', Unzer Moment, 152, 7 July 1936.

${ }^{57} \mathrm{G}-\mathrm{Z}$. 'Baratung fun tsentral rat, tsentral farvaltung un aktive hantverker tuer allitvishn fareiniktn hantverker farband', Unzer Moment, 152, 7 July 1936; 'Oifn allitvishn "verslininkishn" kongres in Shavl zingt men dos alte lidl', Dos Vort, 84, 26 Nov. 1934.

${ }^{58}$ Ish. Sholem, 'Litvishe kremer', Unzer Moment, 92, 27 Nov. 1934. 
A white-bearded Jew, dressed in the white robes of the sage, was saying a prayer. ... Can there be anything more beautiful than sitting in the evening in the prayer house at a wide table with other Jews absorbed in the texts of the Gemara. All day long the mind is 'fed' on ordinary food. To set the prices of herrings and matches here and there. Soon the evening comes and the second part of the day, full of routine worries, begins, and the mind will be occupied with earthly matters. ... Therefore it is no wonder that a Jew hurries to the synagogue for the afternoon prayer, which as a rest from work gives time for more beautiful and spiritual thoughts. ${ }^{59}$

Coming back to the same shop the writer noticed to his surprise that its keeper was the same Jew that he saw in the prayer house, only 'dressed in simple everyday clothes and with a kind-hearted smile on his face instead of his former serious look'. Lastly Sholem asked whether the famous rabbis had engaged in handicrafts after their studies and whether they themselves had been artisans, who like our Lithuanian traders after dark lived cultivating their mind and spirit. The latter variant seems more probable. Our destiny shows that in the twilight we must live a spiritual life. ${ }^{60}$

It is also noteworthy that the article has a strong Zionistic flavour because 'twilight' meant not only the time at the end of the day but also the Jewish life in the Diaspora, which must be passed on the way to the Promised Land. On the other hand, the details of the description draw a picture of the average Lithuanian Jewish trader whose life was far from being easy.

Following each step of the Association of Businessmen, Zionist dailies informed its readers practically about every congress, campaign, declaration, etc. of the Association. ${ }^{61}$ Reading these reports one can learn more about what the Lithuanian businessmen said or

${ }^{59}$ Ibid.

${ }^{60}$ Ibid.

61 'Vi azoi "Verslas" hetst: arum der maise sindikatn', Di Yidishe Shtime, 242, 21 Oct. 1932; 'Geefnt tsuzamenfor fun "verslininkes"', ibid., 303, 8 Oct. 1933; 'Shtarke hetse kegn yidn af verslininkes tsuzamenfor, ibid., 304, 8 Oct. 1933; 'Sharfe rezolutsies fun verslininkes kongres', ibid., 305, 9 Oct. 1933; 'Der verslininkes kongres in Shavl', Unzer Moment, 91, 26 Nov. 1934; 'Oifn allitvishn "verslininkishn" kongres in Shavl zingt men dos alte lidl', Dos Vort, 84, 26 Nov. 1934; Iks, 'Tsum moment: verslininkes tsuzamenfor', Unzer Moment, 92, 27 Nov. 1934; 'Oifn verslininkestsuzamenfor redt men vegn bakemfn shtarker di yidn', ibid., 273, 7 Dec. 1936; 'Vos es viln di verslininkes', ibid., 274, 8 Dec. 1936; 'Hinter di kulisn bai di verslininkes', ibid., 275, 9 Dec. 1936; 'Verslininkes veln aroisheibn in seim gezets frage vegn zuntik ru', ibid., 275, 9 Dec. 1936, etc. 
did rather than what the Jews themselves had to say in each concrete case. Attempts were made to report precisely the speeches of different business activists at various meetings. Only brief introductory remarks, an analysis of the phrases used and a non-accidental usage of punctuation marks give some idea about the emotional situation of the writer and of the effect which such news could produce both on the publishers and on the readers. Writing about the Second Congress of Businessmen, Di Yidishe Shtime noted that people of other ethnic groups were attacked so fiercely that 'the smell of gunpowder seasoned with strong and uncontrolled chauvinism' 62 was felt in the hall. A year later the Third Congress took place, and Unzer Moment accentuated the idea that dominated the speeches of the participants expressed in such remarks as 'a war is going on against the alien race', 'Lithuania for the Lithuanians' and the infamous slogan swój do swoego drew rapturous applause. ${ }^{63}$ The journalist of Dos Vort, who followed the opening of the congress on the radio, was astonished by the pomposity and prominence given to the event. Having briefly reviewed the atmosphere of the opening, the correspondent noted that from the very beginning the speeches contained 'aggressive statements directed against foreigners, in particular the Jews', and shtetl Jews were presented as 'harmful elements that spread like mould' ${ }^{64}$ The tone of the adherents of fascist dictatorship and as well as catchphrases, characteristic of all radical nationalists ${ }^{65}$ were easily discernible in the greetings and inducements of the speakers. The journalist also noticed that the speakers reiterated their previous statements that the economic activity of the foreigners was contrary to the interests of the state and nation (the Lithuanian nation was meant) and di groie sermeges (lit. 'gray overcoats', i.e. Lithuanian peasantry) had to support the businessmen, defending their interests. ${ }^{66}$

62 'Geferlikher veg', Di Yidishe Shtime, 97, 29 Apr. 1933.

${ }^{63}$ To express the atmosphere it was fashionable to use such expressions in the language of the original; in this case allusion was made to the Polish National Democratic propaganda kupuj $u$ swoich [lit. 'buy from your own', i.e. buy Polish]. 'Der verslininkes kongres in Shavl', Unzer Moment, 91, 26 Nov. 1934.

64 'Oifn allitvishn "verslininkishn" kongres in Shavl zingt men dos alte lidl', Dos Vort, 84, 26 Nov. 1934.

65 Jewish syndicates, bank credit policy, double standards in protecting one's own interests were groundless accusations as elements of the theory of the Jewish world conspiracy.

${ }^{66}$ Ibid. 
Incidentally the only article differing in tone and airing its grievances appeared in the Revisionist daily Unzer Moment after the Third Congress. It should to be noted that it was written by the author under the pseudonym 'Iks', often engaging in the polemic against business demagogues in Apžvalga. ${ }^{67}$ The article refutes the myths about Lithuanian Jews as groundless, because the Jews were neither 'newcomers', nor 'parasites', nor 'temporary guests', whose right to live and work in Lithuania equalled 'only a crumb fallen from the beard of the Aryan'. Jewish contribution to the formation of the fledgling Lithuanian economy, international recognition of the state and the question of Vilnius were acknowledged. The article ended by stating:

Luckily, the Lithuanian peasant is a man of sound, rational mindset, and he understands that he definitely needs his Jewish neighbour no less than he did yesterday, and that is attested by faces expressing regret. It is to be hoped that the villager will grasp the real intentions of the false patriots and will not be misled. The case is much worse with the new town dweller, who has broken in with an enormous appetite and it seems to him that he can rule the world that 'the Jews have usurped'. The task of the ruling circles is to weaken their unhealthy appetite and objectively regulate the relations between the former and the new inhabitants of the towns on the basis of law, humanism and equality. ${ }^{68}$

The everyday businessmen propaganda, instigating 'to put an end to the domination of the alien newcomers, ... to boycott the foreigners, to buy only in Lithuanian shops, because Lithuania is for the Lithuanians, and the town like the village must be Lithuanian' disagreed with President Smetona's speech, which accentuated that 'Lithuania is the fatherland of all ethnic groups that dwell within it'. Di Yidishe Shtime presented this statement as a model of genuine patriotism and the guidelines to stick to and thereby expressed a doubt: 'Will they [the businessmen - E. B.] act like that? And are they willing to ...?'.69

The reflections of the economic Lithuanian-Jewish rivalry in the Zionist dailies do not clearly reveal the position of the Lithuanian

${ }^{67}$ Iks, 'Tsum moment: verslininkes tsuzamenfor', Unzer Moment, 92, 27 Nov. 1934.

${ }^{68}$ Ibid.

69 'Di Mehusnim', Di Yidishe Shtime, 146, 30 June 1936; 'Hetserishe proklamatsie fun di verslininkes vert farshpreit oif der oisshtelung', Unzer Moment, 145, 29 June 1936. 
Zionist organisation proper. On the one hand, it could be surmised that the policy of the Lithuanian government to treat the Jews as a temporary useful economic element while the modern Lithuanian political nation had not yet fully recovered politically and economically and at the same time to ensure the loyalty of the largest ethnic minority, and the Zionist position to treat life in the Diaspora as a temporary transitory existence until the rise of a new nationally conscious Jewish nation, had much in common and were mutually advantageous. On the other hand, the situation in the country and in the Zionist organisation itself had undergone radical changes due to various internal and external transformations in the "thirties. The concern for Palestinian matters remained prominent, and the attention of the Zionists to Lithuania's internal affairs increased. The after-effects of the world Depression, the rise of Nazi Germany, and emigration restriction made the idea of the National Home still more attractive for many Jews out of practical consideration. Britain's reducing the immigration quota for Palestine every year made the situation of the Zionist organisation desperate, since the numbers of those willing to emigrate were far greater. Therefore the Zionist organisation in Lithuania concentrated its efforts into the search for 'labour and bread' in the native country of the Jews instead of their historical Fatherland.

Dealing with the manifestations of the government's protectionist economic policy the Zionist press performed its primary function - informing its readers. Anonymous articles (their overwhelming majority was unsigned and distinguished by their moderate tone) expressed collective opinions on economic issues, relevant not only to a particular social layer but to the entire Lithuanian Jewish community.

The concern over the tendency of eliminating the Jews from the economic positions and the reaction to restrictions were quite natural. It was evident that in economic competition the Lithuanian businessmen exploited patriotically disguised national motives. To counter the propaganda tone of Verslas, Mūsu žemé, Ükininko patarejas and other Lithuanian newspapers, the Zionist press resorted to the role of the lawyer, and it is noteworthy that in this case the titles and the content of the articles were more eloquent, too. It was clear that the described events and actions were identified as anti-Jewish. However, the abstention from commentaries and the absence of a clear unequivocal position with respect to the propa- 
ganda of Lithuanian businessmen lead to two conclusions: either an endeavour to avoid pouring oil on the fire or the supposition that the reader was literate enough to understand not only what was written but also what was implied. Besides, the articles, informing every day about the worsening situation of the Jews in Germany, Poland, Romania, Hungary, Ukraine, etc., enabled the readers to grasp the rhetoric of the right-wing radicals.

Translation: Alfonsas Laučka

\section{Author Details}

Dr Egle Bendikaite is a junior researcher of the Lithuanian Institute of History. Her field of interest is the history of the Jewish ethnic minority and the history of the everyday Jewish-Lithuanian relations in interwar Lithuania.

Address: Department of Twentieth-Century History, Lithuanian Institute of History, Kražių 5, LT-01108 Vilnius, Lithuania

Email: egle_bendich@yahoo.de

\section{LIETUVIŲ IR ŽYDŲ EKONOMINĖS KONKURENCIJOS ATSPINDŽIAI SIONISTINËJE SPAUDOJE XX A. IV DEŠIMTMETYJE}

Santrauka

\section{EGLE் BENDIKAITE}

Socialinis ekonominis faktorius lietuvių ir žydų santykiuose tarpukariu buvo bene svarbiausias, todèl jis jau yra analizuotas įvairiais rakursais lietuvių ir žydu autorių darbuose. Šio straipsnio tikslas - pabandyti pažiūrèti i „,kitoje barikadų pusėje“ buvusius proceso dalyvius, atskleidžiant, kaip ekonominè konkurencija tarp lietuvių ir žydų buvo suprantama ir pateikiama ketvirtojo dešimtmečio sionistinejje spaudoje, kurios buvo gausiausia ir kurią skaitė įvairiu politinių įsitikinimų žmonès.

Lietuvos valdžios politika sudaryti palankias sąlygas tarpti lietuviškajam kapitalui buvo sąlygota natūralaus poreikio pakeisti per šimtmečius susiklosčiusias disproporcijas etniniu pagrindu pramonès, prekybos, amatų ir laisvujų profesijų veikloje. Lietuvos žydai netruko pajusti permainas tose ūkio šakose, kurioms valdžia parodè „ypatingą dèmesį“. Sionistinèje spaudoje buvo informuojama apie konkrečius Lietuvos nacionalinès programos ekonomikoje vykdomus žingsnius, neliko nepastebèti ir didžiausią ažiotažą žydų bendruomenèje sukèlę „Eksporto ir importo“, „Amatininkų kvalifikacijos egzamino“, „Švenčių ir poilsio dienų“ istatymai bei jų pataisos.

1930 m. issikūrusi lietuvių prekybininku̧, pramonininkų ir amatininkų sajunga, lietuvių ir žydų tarpusavio kultūrinio skirtingumo bei nesutaikomumo idejjai pagrịsti vartojusi ekonominio gyvenimo kategorijas, netruko atsidurti sionistinès spaudos puslapiuose. Buvo stengiamasi preciziškai tiksliai atkartoti kasdienybe tapusią lietuvių verslininkų specifinę retoriką bei propagandą. Ir tik trumpos ịvadinès pastabos bei vartojamų žodžių junginių ar neatsitiktinai padètų skyrybos ženklų analizè leidžia spèti, 
kokia buvo emocinė rašiusiojo būklè ir kokị efektą tiek laikraščių leidèjams, tiek skaitytojams galèjo sukelti tokio pobūdžio naujienos.

Rašydama apie valdžios protekcionistinès ekonominès politikos apraiškas, sionistine spauda pirmiausia imdavosi savo tiesioginès, t. y. visuomenès informavimo funkcijos. Rūpestis dèl stebimų kryptingų eliminavimo iš užimamų ekonominių pozicijų pagal tautybę tendencijų bei noras atitinkamai reaguoti $i$ iš to išplaukusius žydu suvaržymus praktikoje atrode natūralus. Nereikejjo didelių pastangų suprasti, kad ekonominėje konkurencijoje lietuviai verslininkai naudojo tautinius motyvus, pridengtus patriotizmo dvasia. Kad atremtu „Verslo“, „Mūsų žemès“, „Ūkininko patarèjo“ ir kitų lietuviškų laikraščiu propagandinį toną, sionistinè spauda griebdavosi advokato vaidmens, tačiau ir šiuo atveju reikia pažymèti, kad iškalbingesnès buvo straipsnių antraštès, nei jų turinys. Buvo aišku, kad aprašomi i̇vykiai ir veiksmai yra identifikuojami kaip antižydiški. Tačiau susilaikymas nuo komentarų ir aiškios vienareikšmiškos pozicijos lietuvių verslininkų kurstančios propagandos atžvilgiu nebuvimas leidžia daryti dvi prielaidas: arba buvo vengiama ,šliūkštelèti į ugnị dar daugiau alyvos“, arba jų skaitytojas buvo pakankamai išlavintas perskaityti ne tik spausdinamą informaciją, bet ir perprasti tai, kas likdavo tarp eilučiuc. 